\title{
Metafoor en waarheid
}

G M J van Wyk

Vanderbijlpark

\begin{abstract}
Metaphor and truth

In the past metaphors were researched by means of theories. These theories on metaphors were developed as language theories or studies on the philosophy of language. Even when philosophical studies on the metaphor went beyond the philosophy of language, they still focused on language. In dialogue with the philosophers Aristotle, Kant and Nietzsche, and the theologian Luther, this study concentrates on broadening the context of research on the metaphor to that of a contemporary critique of reason. The result of this approach is not only that metaphors are researched from within a new perspective, but also that the relation between metaphor and rationality is reviewed to the extent that it is argued that rationality and even reality show a metaphorical structure at times. A narrative approach has also proved to be a more successful means of research on metaphors, than a theoretical approach.
\end{abstract}

\section{INLEIDING}

Navorsing oor metaforiek is in die verlede aan die hand van metafoorteorieë gedoen. Die metafoorteorieë is as taalteorieë of taalfilosofiese studies aangebied met die gevolg dat metafore byna uitsluitlik binne die konteks van 'n taalstudie aan die orde gestel is. Selfs waar filosofiese studies die grense van die taalfilosofie oorskry het, het die hooffokus daarvan die taal gebly. Hierdie artikel wil daarop konsentreer om die bestudering van metaforiek uit die eng taalkundige konteks waarin dit tradisioneel bestudeer is, los te maak en dit binne die konteks van die eietydse redekritiek aan die orde stel. Die gevolg van hierdie benadering is nie alleen dat daar vanuit 'n nuwe perspektief na metafore gekyk kan word nie, maar ook dat die verhouding tussen metaforiek en rasionaliteit bedink word en dat daar aangetoon word dat rasionaliteit, en selfs die werklikheid, by tye 'n metaforiese struktuur vertoon.

\section{ARISTOTELES}

Voordat ons by Aristoteles se beskrywing van metafore stilstaan, is dit nodig om eers in die algemeen iets oor sy mensopvatting te sê. Die rede hiervoor is dat hy self die uitgangspunt vir sy metafoorteorie in die antropologie vind. Om te leer, sê hy, is vir 
alle mense 'n genot en 'n vreugde (Ars rhetorica $\Gamma, 1410 \mathrm{~b} 10$ ). Elke mens het 'n natuurlike drang om te weet. Dit is egter ook 'n eienskap van die mens dat hy niks wil doen wat nie nodig is nie. Onnodige aktiwiteit is vir hom vermoeiend en daarom vermy hy dit (De caelo A, 271a 33). Die mens wil net met dié dinge besig wees wat hom kan help in sy selfverwerkliking. Dit beteken dat die mens sy natuurlike begeerte tot kennis op die maklikste wyse wil bereik. Hoe gouer dit gebeur, hoe beter (Ars rhetorica $\Gamma, 1410 \mathrm{~b} 21)$ !

Maar wat is kennis? Wat is hierdie kennis waarna elke mens streef? Kennis, verduidelik Aristoteles, is taal wat op só 'n wyse op die werklikheid betrek word dat die wese van sake aan die lig kom. Om te weet, beteken om te kan sê wat is. Kennis is daarom op taal aangewese en taal is op die gebruik van woorde aangewese. Woorde benoem dinge (sake) en daarom kan woorde iets beteken. Metafore is ook taal wat met kennis te make het, daarom neem Aristoteles sy vertrekpunt vir die ontwerp van 'n metafoorteorie in sy taalteorie (Ars rhetorica $\mathrm{r}, 1410 \mathrm{~b} 11$ ).

Aristoteles bespreek die metafoor wanneer hy oor die sogenaamde 'naamwoorde' handel (Categoriae et liber de interpretatione 3.16b 20-21). Die metafoor is 'n naam ǒ $\nu \rho \alpha \alpha$. Die uitdrukking 'naam' word egter nie hier in sy alledaagse beperkende betekenis aangewend nie, want dit wil eerder aandui dat die metafoor as 'n teken verstaan moet word. ' $n$ Naam benoem iets. Dit is 'n 'noemwoord' en daarom is dit ook 'n teken. 'n Naam is 'n klank wat 'n simbool geword het en gevolglik iets kan aandui, met ander woorde, die wootd is 'n teken, nog voór dit as metafoor ingespan word. Dit word nie eers ' $n$ teken wanneer dit as metafoor gebruik word nie.

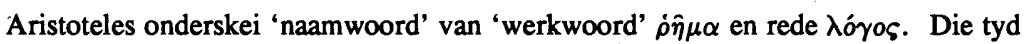
is altyd medebepalend by dit wat 'n werkwoord aandui, terwyl tyd nie die betekenis van 'n naamwoord beïnvloed nie. Die rede verskil weer van die naamwoord daarin dat die verskillende dele van die rede betekenis kan hê, omdat die rede uit sowel name as werkwoorde opgebou word, terwyl 'n naamwoord net as geheel iets beteken. Die rede se funksie is om altyd iets as waar aan te dui, of dit as vals af te wys. Hierdie aannemende of afwysende taalgebeure vorm 'n eenheid wat die syn van die sake wat bespreek word, aan die lig laat kom (Categoriae et liber de interpretatione1 3.17a 23-26). Semanties gesien, is die rede altyd 'n beoordelende uitspraak en daarom is dit moontlik dat die taal (of dan rede) die oord is waar die waarheid aan die lig kom. Alleen taalgebeure, wat die wese van die werklikheid belig, kan op waarheid aanspraak maak. Alle ander taalgebeure het nie direk die funksie om die waarheid aan die lig te bring nie en daarom kan dit nie by wetenskaplike ondersoeke ingespan word of vir definiëring gebruik word nie (Categoriae et liber de interpretatione $3.17 \mathrm{a} 8 \mathrm{e}$ v). 
Retoriek is nie oorbodig omdat dit nie in wetenskaplike ondersoeke gebruik kan word nie. Die waarheid moet ook gepropageer word (Ars rhetorica A, 1355a 21-24). Daarom word woorde ook op so ' $n$ manier ingespan dat die kennis wat reeds verwerf is, op 'n nuwe manier ter sprake kom. Dit gebeur deur woorde nuut te gebruik. Hierdeur word kennis ook uitgebrei. Deur die ongewone gebruik van woorde, word die uitbreiding van kennis gedien. Hier kom die gebruik van metafore ter sprake.

Van nature is die waarheid sterker as die leuen, maar die mens as taalvaardige wese, het al in die verlede gehelp dat die leuen oor die waarheid seëvier. Die mens moet egter probeer om dit wat hy verbrou het, deur daaraan mee te werk dat die waarheid verduister word, reg te stel. Hy kan dit doen deur 'n retoriese verantwoordelikheid vir die waarheid te aanvaar. Hierdie verantwoordelikheid vra van die mens dat hy die waarheid met sy retoriese vaardighede sal bevorder. 'n Deel van die mens se retoriese vaardigheid is die gebruik van name. Waar name gebruik word, kom die gebruik van metafore ook tot hulle reg (Ars rhetorica A, 1355a 21-24).

Aristoteles onderskei tussen kì $\rho\llcorner\nu$ of werklike (heersende) name en $\gamma \lambda \omega \tau \tau \alpha$ of vreemde name (De arte poetica liber $1457 \mathrm{~b} 4$ ). Die metafoor behoort tot die kategorie van vreemde name. Dit wil egter nie sê dat die metafoor 'n totale vreemde woord, soos 'n woord uit 'n vreemde taal is nie. Die metafoor is 'n woord wat tussen die gewone heersende- en ongewone gebruik van die woord rondspeel. Op 'n speelse manier word twee sake waarmee die mens vertroud is, op so 'n wyse met mekaar in verband gebring dat die mense wat aangespreek word, nuwe insig kry. Om dit in terme van Gadamer te sê: Twee onafhanklike betekenishorisonne word saamgevoeg om 'n nuwe horison te skep.

Die gebruik van metafore veronderstel die moontlikheid dat die wêreld van die dinge sonder metafore beskryf kan word. In werklikheid kan die aanname dan ook geld dat eintlike name gebruik word om hierdie sake te beskryf. Eintlike name kry hulle semantiese funksie op grond van 'n betekenisgewende ooreenkoms wat tussen woord en saak deur taalgebruik ontstaan. Die metafoor, daarteenoor, wyk van die heersende taalgebruik af - in elk geval wanneer dit ontstaan.

Metafore word teenoor die heersende taalgebruik gehandhaaf, omdat mense die kuns verstaan om metafore as vreemde woorde nie te verdring nie, maar dit staande te laat bly. Dit beteken dat die betekenis van 'n metafoor nie aan die willekeur oorgelaat is nie, maar dat dit hermeneuties noukeurig bepaal word. Gevalle waar die gebruik van metafore geoorloof is, is die volgende: Wanneer ' $n$ vreemde naam van ' $n$ genre op ' $n$ genus, of van 'n genus op 'n genre oorgedra word, of wanneer ' $n$ vreemde naam van 'n genus op 'n ander genus oorgedra word, of deur die gebruik van 'n analogie (De arte 
poetica liber 1457b 4-8). Die volgende voorbeelde kan die saak toelig: 'My skip lê hier' is ' $n$ voorbeeld waar genre op genus oorgedra word, want 'om voor anker te lê' is 'n genus van 'lê'. 'Odusseus het tien duisend edel dade verrig' is 'n geval waar genus op genre oorgedra word, want 'tien duisend' is 'n genre van 'baie'. 'n Geval waar een genus op ' $n$ ander oorgedra kan word, is die volgende: 'Ek teken my lewe met brons (nl 'n spies) af' en 'Ek sny met skerp brons (nl 'n mes)'. Hier kan 'teken' die betekenis van 'sny' hê en 'sny' kan die betekenis van 'teken' hê. Die eerste uitdrukking sou dan beteken om jou lewe te neem en die tweede om iets met 'n skerp voorwerp te skryf of te teken. 'n Voorbeeld van metaforiese analogie is die volgende: " $n$ Beker staan in verband met Dionisus net soos wat 'n skild met Ares in verband staan'. Daar kan egter van 'Die skild van Dionisus' gepraat word, met die bedoeling dat 'skild' ' $n$ metafoor vir 'beker' is (De arte poetica liber 1457b 9-14).

Die analogies opgeboude metafoor het besondere waarde omdat dit vir die beskrywing van sekere sake onontbeerlik is. Dit gebeur in gevalle waar 'n eintlike - en in die taal gebruik heersende beskrywing - van bekende sake algeheel ontbreek, byvoorbeeld: ek daal af tot by die poorte van die doderyk. In sulke gevalle is die gebruik van metafore dwingend (De arte poetica liber 1457b 25-30).

Behalwe vir die laasgenoemde noodgeval, is die gebruik van metafore nie noodsaaklik nie, maar 'n taal sonder metafore is afgestomp en vaal. Taal kan baie kleurryker gemaak word wanneer die taalgebruiker in staat is om metafore op so 'n manier aan te wend dat dit nie kunsmatig lyk nie, maar natuurlik. Dit gebeur wanneer metafore, in plaas van die heersende taalgebruik, op so ' $n$ manier ingespan word dat 'n saak op so ' $n$ wyse deur die taal verberg word, dat die spreker tog nog helder en duidelik verstaan kan word. Waar dit gebeur, word die indruk geskep dat die metafoor - en geen ander vorm van taal nie - die gepaste taalvorm is om te gebruik.

Nie alle mense is in staat om metafore te ontdek nie. Dit is nie ' $n$ kuns wat van ander geleer kan word nie, want dit is ' $n$ natuurlike gawe wat net sommige mense besit. Om metafore te kan ontdek, moet mens 'n fyner estetiese oordeel as die meeste ander mense hê (De arte poetica liber 1459a 6 e v).

'n Metafoor moet volgens die struktuurwet van die analogie opgebou wees om te kan slaag. Wanneer dit gebeur dà 'n metafoor volgens hierdie wet opgebou word, bring dit die werklikheid ter sprake. Dit beteken dat 'n geslaagde metafoor mense 'n blik gee op dit wat die wêreld ten diepste tot 'n eenheid saambind (Ricoeur 1981:179181). Metafore gee mense insig in die heelheid van die werklikheid. Metafore hou vir die mens ' $n$ wins in. Deur die taal word die werklikheidshorison van die mens verruim. Metafore is ' $n$ besondere wyse van taalmatige omgang met die werklikheid (Ars rhetorica $\Gamma, 1410 \mathrm{~b} 14 \mathrm{e} \mathrm{v}$ ). 
Uit die bogenoemde argument konkludeer Aristoteles dat die gebruik van metafore ook ' $n$ logiese aangeleentheid is. Die gebruik van metafore bring 'n implisiete tendens tot logiese begripsbou aan die lig. Hierdie tendens tot logiese begripsbou bestaan in die bemiddeling van kennis tussen mense, op so 'n wyse dat die gemeenskaplike op 'n uitsonderlike manier, en die gelyke op 'n ongelyke wyse gesê word. Metafore is nie nabootsing nie, maar nuwe skeppings of konstruksies.

'n Vereiste vir die gebruik van 'n metafoor is dat die hoorder ook die metafoor sal verstaan. Gebeur dit, dan is die metafoor vir sowel die spreker as die hoorder ontdekkende taal. Nog meer, dit wat ontdek is, word op so 'n wyse aan die lig gebring dat die ontdekkingsproses ook by die vertelling betrek word en dit ook beskryf word (Ars rhetorica $\mathrm{B}, 1400 \mathrm{~b} 29-33$ ).

Die gebruik van metafore kan egter ook 'n gevaarlike aangeleentheid word. Mense moet baie versigtig met metafore omgaan, sodat hulle die gevaar wat metafore inhou, kan vermy. By die ontstaan van metafore kom dit daarop neer dat die metafoor moet slaag; dit wil sê, dat die metafoor die werklikheid werklik ter sprake sal bring, al sê dit ook meer oor die werklikheid, as wat dit in der waarheid moet sê. Geslaagde metafore herhaal die verruiming van die werklikheidshorison op so 'n treffende manier dat die een wat die metafoor hoor, die verruiming wat ter sprake is, kan snap. Wie goeie metafore hoor, gaan deur 'n leerproses. Hierdie mense se werklikheidservaring word verruim, omdat hulle kennis verbreed. Hierdie leerproses het egter 'n speelse karakter en daarom is dit baie aanloklik. Die gevaar van metafore lê daarin dat dit tussen werklikheid en skyn rondspeel. Wanneer metafore egter die skyn, in plaas van die werklikheid, propageer, triomfeer die metaforiese skyn oor die metaforiese werklikheid en mislei dit die mens en bevorder dit die leuen.

Aritoteles se metafoorteorie het 'n baie sterk nawerking gehad. Dit het die uitgangspunt gevorm vir 'n algemeen aanvaarde klassieke opvatting oor metafore, al het hierdie opvatting op sommige fundamentele punte van die standpunt van Aristoteles afgewyk. Wat in hierdie gepopulariseerde opvatting voorop staan, is die mening dat metafore nie as presiese wetenskaplike taal kan geld nie. As taalvorm is die metafoor deel van die retoriek, wat nie as presiese wetenskaplike taal beskryf kan word nie.

Deur taal, so lei die populêre tradisionele standpunt, kan 'n mens 'n saak eenduidig ter sprake bring deur sekere woorde met vaste betekenisse te gebruik. Hierdie woorde word op so 'n wyse in sinne verbind, dat eenduidige uitsprake oor die werklikheid geformuleer word. Elke woord het 'n tekenfunksie, met ander woorde, die semantiese $\sin$ of die sogenaamde woordinhoud korrespondeer met die betekenis, of die referensiële saak daarvan. Die woord het 'n werklikheidskonteks wat deur 'n taalkonteks uitgespreek word op so 'n wyse dat sowel die spreker as die hoorder dit verstaan. Deur eenduidige uitsprake kom die spreker en die hoorder tot 'n gemeenskaplike verstaan van 'n saak. 
By die gebruik van metafore staan sake egter anders. 'n Gemeenskaplike verstaan van ' $n$ saak kan hier nie op dieselfde wyse ontstaan as by die gebruik van uitsprake tussen die spreker wat hom van 'n metafoor bedien, en die hoorder wat die gebruik van die metafoor nie te wagte is nie. Die spreker wat 'n metafoor gebruik, breek uit die gebruik van gebruiklike taalvorms. Die hoorder ken wel die woorde wat die spreker gebruik, maar is aanvanklik nog nie vertroud met die nuwe taalkonteks en werklikheidskonteks wat ter sprake kom nie. Die spreker vertrou egter daarop dat die hoorder hom sal verstaan, omdat die ou en die nuwe werklikheidskonteks so na aan mekaar lê dat die hoorder die nuwe betekeniskonteks wat ter sprake kom, self sal kan aflei. Dit is nie vanselfsprekend dat 'n hoorder 'n metafoor sal verstaan en so tot 'n gemeenkaplike verstaan met die spreker kom nie. Metaforiese taalgebruik het egter ' $n$ besondere krag om mense aan te spreek. Mense ervaar die skoonheid van 'n metafoor baie gunstig en daarom reageer hulle wel maklik op 'n metafoor. Metafore is ' $n$ luukse. Dit is nie iets wat onontbeerlik is nie. Dit is egter 'n taalvorm waarvan mense hou; 'n taalvorm wat hulle laat voel dat hulle aangespreek word, daarom word dit - omdat die taal wat gebruik word, mooi klink - dikwels aangewend.

Jüngel (1980:133) het bedenkinge oor die essensie van hierdie geykte opvatting. $\mathrm{Hy}$ is van mening dat wanneer die vraag na die funksie van die metafoor gevra word, die tradisionele standpunt al die klem op die reeds gediskrediteerde aanspreekkarakter van die metafoor plaas. Die vraag kan egter gevra word of die aanspreekdimensie van minder belang as die uitspraakdimensie van taal is. Taal as aanspreke is nie vreemder aan die waarheid as wat taal as uitsprake is nie. Habermas se teorie van die kommunikatiewe handeling kan ter ondersteuning en verduideliking van Jüngel se kritiek dien. Habermas (1983:76) onderskei tussen die deelnemersperspektief en die waarnemersperspektief by taalgebruikers. Daar is sekere sake wat eenvoudig net nie uit die perspektief van 'n waarnemer bevredigend beskryf kan word nie, omdat dit net effektief beskryf kan word vanuit die standpunt van 'n deelnemer aan die kommunikatiewe handeling. Hierdie taalvorm is nie minder noukeurig of vals, bloot omdat dit nie vanuit ' $n$ waarnemersperspektief geformuleer is, of sogenaamd objektief is nie. Ons moet eerder aanvaar dat taal wat uit ' $n$ deelnemersperspektief geformuleer word, nie mank gaan aan rasionaliteit nie, maar dat 'n ander styl van rasionaliteit die grondslag vir hierdie taalvorm lê. Ons moet rasionaliteit nie beperk tot instrumentele rasionaliteit nie. In die lig van Habermas se redenasie kan die vraag van Jüngel met oortuiging herhaal word. Waarom ken die tradisionele taalteorie so 'n geweldige primaat aan uitsprake teenoor aanspreke toe, wanneer die waarheidsvraag binne die linguistiese konteks ter sprake gebring word? In terme van Aristoteles se eie filosofie kan hierdie vraagstuk dalk soos volg verwoord word: Het die populêre metafoorteorie nie 
Aristoteles se onderskeid tussen die ontdekking van waarheid en die propagering daarvan misverstaan nie? Staan aanspreke, retoriek en propaganda heeltemal los van die waarheidsvraag?

Dit is wel so dat metafore baie gebruik word om taal op te smuk, maar dit is ook so dat daar gevalle bestaan, waar die gebruik van metafore 'n noodsaaklikheid word om 'n saak bevredigend te kan beskryf. Laasgenoemde is die geval omdat daar sake is waaroor daar wel gepraat kan word, maar waarvoor daar nie enige verbum proprium bestaan wat ' $n$ eenduidige betekenis het, sodat die saak daarmee beskryf kan word nie. Hierdie feit plaas ' $n$ vraagteken agter die hele tradisionele metafoorteorie en dié teoriese verwerking van die standpunt van Aristoteles (Jüngel 1980:134).

Die standpunt van Aristoteles kan met groter vrug in ' $n$ ander rigting ontwikkel word. In aansluiting by Aristoteles kan daarop gewys word dat metafore die begripsdefiniëringsfunksie van noemwoorde kan oorneem wanneer dit nodig word. Wat egter van nog groter belang is, is die feit dat die metafoor ' $n$ grondvorm van aansprekende taalgebruik is. Dit moet benadruk word dat die bestaan en wye gebruik van aansprekende taalgebruik sterk daarop dui dat alle taal altyd 'n relasie tot uitdrukking bring - 'n relasie tot die wêreld, tot die 'ek' wat aan die woord is, en 'n relasie tot die ander wat hoor of waaroor gepraat word. Is hierdie relasies veel anders in aansprekende taalgebruik as in uitsprake oor sake? Wat uit hierdie waarneming aan die lig kom, is nie dat sekere relasies getrouer aan die waarheid is as ander nie, maar dat die gebruik van woorde eerder 'n geskiedenis het wat uit die geskepte taalrelasies afgelei kan word. Woordbetekenis verskil vanweë die feit dat woorde geskiedenisse het. Woorde se betekenis word medebepaal deur die beweging van die taal. In hierdie beweging van taal word woorde op ' $n$ bepaalde tyd tot 'n eenheid saamgevoeg om 'n uitspraak te vorm. 'n Woord het 'n hele aantal betekenismoontlikhede. By die formulering van uitsprake word hierdie moontlikhede gereduseer. So gebeur dit dat sekere woordbetekenisse deur 'n hoë gebruiksfrekwensie meer prominent word. Hierdie verskynsel neem egter nie die feit weg dat woorde steeds 'n wye spektrum van gebruikspotensiaal het nie. Dat dit so is, gee aan taal 'n gelykeniskarakter. Dit beteken dat daar by mense ook ' $n$ neiging en 'n behoefte bestaan om die gebruikspotensiaal van woorde te bly ontgin, al is die reduksionistiese krag van uitsprake ook in die taalgeskiedenis aan die werk. Die feit dat die ontginning van gebruikspotensiaal steeds ' $n$ moontlikheid vir enige taalgebruiker is, is in die metaforiese struktuur of pluraliteit van betekenismoontlikhede van woorde geleë. Die metaforiese struktuur van taal maak woord- en begripsgeskiedenis moontlik (Jüngel 1980:135). 


\section{LUTHER}

Die denke van Martin Luther kan as 'n voorbeeld dien om aan te toon dat die tradisionele metafoorteorie vroeg reeds betwis is aan die hand van die opvatting dat metafore 'n gelykeniskarakter, eerder as 'n tekenkarakter, vertoon.

Anders as Aristoteles wil Luther metafore soos 'Christus is die rots', 'Christus is die ware wynstok', of 'Christus is 'n blom' as werklike name verstaan en nie as vreemde name nie. Luther beveg die onderneming van $\mathrm{Zwingli}$ wat die genoemde spreuke as voorbeelde voorhou, om sy argument te staaf dat die koppelwoord 'is' ook in die omstrede instellingswoorde by die nagmaal 'Dit is My liggaam', in der waarheid die betekenis van 'beteken' moet hê. Vir Luther beteken hierdie spreuke presies dit wat hulle sê. Christus is die rots, die ware wynstok, of 'n blom en die nagmaalsbrood is die liggaam van Christus. Luther voer aan dat dit logies onsinnig is om te sê: Christus beteken die rots, die ware wynstok, ensovoorts. Natuurlik is dit die geval dat die predikate in die genoemde voorbeelde nuwe betekenisse kry. Dit is dan ook, volgens Luther, die opvatting van al die grarnmatici en die retorici dat die predikatief gebruikte woord in 'n metafoor 'n nuwe woord word. Die predikatief gebruikte woord word 'n nuwe woord en kry 'n nuwe betekenis. By die spreuk 'Christus is 'n blom' beteken die woord 'blom' nie meer die blom in die veld nie, maar die kind Jesus. Daarom beteken Christus nie 'n blom nie, maar is hy ' $n$ blom, al is dit ' $n$ ander blom as die een in die veld, naamlik die natuurlike blom (WA 26, 272,2-6; WA 26, 499509).

Luther meen, net soos Aristoteles, dat woorde 'n heersende of werklike betekenis het. Word 'n woord egter as metafoor ingespan, kry dit 'n nuwe betekenis of word dit 'n nuwe woord. Wat hier gebeur, is geoorloof in gevalle waar daar tussen beide sake wat deur dieselfde woord aangedui word, 'n ooreenkoms of ' $n$ analogie bestaan. Luther sê taal is deurtrek van sulke gevalle. Die grammatika noem die gevalle waar daar aan twee dinge een naam gegee word, metafore (WA 26, 273,5-11).

Luthei ontken dit dat metafore nie werklike name is nie, maar wel vreemde-name. Teenoor Zwingli se rasionalistiese interpretasie van metaforiese taal as dat die kopulatiewe 'is' van die metafoor eintlik vervang moet word met die woord 'beteken', neem Luther sy vertrekpunt daarin dat metaforiese taalgebruik 'n skeppende krag besit. Hierdie skeppende krag het tot gevolg dat die predikatiewe woord in so 'n mate 'n nuwe woord word, dat die kopulatiewe 'is' letterlik verstaan moet word. 'n Metafoor is volgens Luther niks anders as 'n toutologie nie. Dit beteken dat mens nie 'n onderskeid kan maak tussen die werklike betekenis en die vreemde betekenis van 'n naam nie.

As ons ' $n$ poging sou aanwend om Luther se standpunt in die ontologiese taalgebruik van Aristoteles te vertaal, sou ons dalk die volgende kan sê: Metaforiese taalgebruik het ontologiese relevansie, omdat dit 'n nuwe werklikheidsamehang aan die lig 
bring wat in ' $\mathrm{n}$ uitbreiding van die taalhorison gegrond is. Die nuwe (metaforiese) gebruik van 'n woord gee aan die woord 'n nuwe betekenis en bring daarmee die nuwe betekenis van die nuut ontdekte werklikheidsamehang tot uitdrukking (WA 26, 274, 5 7). Luther gaan met ander woorde van die veronderstelling uit dat die ou betekenis of die werklike betekenis van die woord deur die gebruik van die metafoor, in 'n mate gedekonstrueer word.

Die metafoor neem die moontlike nie-syn van die wêreld waar wat in 'n begrip tot uitdrukking gebring word, deurdat dit die natuurlike saak (bv 'n wynstok) suspendeer om die syn van die wêreld nuut ter sprake te bring. Dit is egter alleen moontlik omdat die nuwe syn wat aan die lig kom, slegs in 'n gelykenis uit die ou wêreld uitspreekbaar is. Luther verstaan die metafoor as die suiwerste vorm van gelykenistaal. Hy moet veronderstel dat sommige werklikheidsverskynsels self gevolglik ook gelykenismatig of analoog is, of dat daar gelykenisse in sekere sake bestaan om taal nie as eenduidige tekentaal te verstaan nie, maar as meerduidige gelykenistaal (WA 26, 273,7 e v). Dit beteken dat daar nie in taalgebruik ' $n$ een tot een relasie tussen woord en saak en woorde onderling voorop staan nie, maar eerder 'n aantal meerduidige relasies. Die analogie tussen die werklikheidsverskynsels maak die praat in gelykenisse moontlik. Wie in gelykenisse praat, maak nuwe en ander woorde uit werklike name (WA 26, 277,8-11).

Luther se standpunt kom egter nog duideliker aan die lig as ons 'n uitspraak van hom in berekening bring wat 'n heel ander saak onder woorde bring. By die uitleg van die eerste gebod sê Luther in sy Groot Kategismus: 'Worauf Du nun (sage ich) Dein Herz hängest und verlässest, das ist eigentlich Dein Gott' (WA 30 I 133). Luther verduidelik sy standpunt soos volg: Hy begin deur die vraag te vra: wat is God? Hy antwoord dan: 'n God is dit van wie mens al die goeie verwag en na wie jy jou toevlug neem in nood. Om 'n God te hê, is dus niks anders nie as om van harte op Hom te vertrou en in Hom te glo. Dit is alleen die vertroue en die geloof van die mens se hart wat beide die geloof in God en 'n afgod tot gevolg het. Is jou geloof en vertroue reg, dan dien jy die regte God, en omgekeerd: waar jou vertroue vals en verkeerd is, daar is ook die regte God nie vir jou daar nie. Van huis uit hoort geloof en God by mekaar.

In sy redenasie laat Luther iets blyk van sy opvatting oor metafore. Wanneer Luther probeer sê wie of wat God is, kan hy dit nie anders sê as om oor die mens en sy geloof in God te praat nie. Volgens hom hoort God en geloof bymekaar. As ons hierdie gedagte taalteoreties sou probeer vertaal, sou ons dalk kan sê dat Luther probeer om die volgende tot uitdrukking te bring: ons taal is wêreldse taal met wêreldse woorde wat op wêreldse sake betrek is en so die werklikheid wil probeer beskryf. Ons ken geen ander predikate as wêreldse predikate nie. Ook die woord 'God' is 'n wêreldse woord. As ons oor dié dinge wil praat wat die horison van ons wêreld oor styg, kan ons ook op geen ander manier daaroor praat as deur wêreldse taal te gebruik nie. Dit 
beteken dat ons - wanneer ons die woord 'God' op ons lippe neem - 'n stuk van ons wêreld in die oog kan hê, met die gevolg dat ons god 'n afgod word. Dit beteken verder dat elke keer wanneer 'n mens probeer om iets van God te sê en hy bedoel dit wat hy sê letterlik, hy besig is om oor die wêreld te praat en dit maak van sy god 'n afgod. Die verskil tussen die wêreld en God self kan net metafories ter sprake gebring word, want 'n mens kan net van God praat, wanneer jy metafories oor Hom praat, naamlik in terme van jou geloof in die ware God. Die ou stelling is waar: Deus definiri nequit.

Uit die bogenoemde argument kan dit duidelik afgelei word dat Luther nie die mening van Aristoteles deel dat analogies opgeboude metafore net in enkele noodgevalle waar ' $n$ heersende beskrywing van bekende sake algeheel ontbreek, onontbeerlik is nie. Die noodgevalle waarvan Aristoteles praat, sou in elk geval so baie wees en vir die mens sake van só 'n groot belang wees, dat dit nie as 'n uitsondering op die reël verstaan kan word nie, maar eerder 'n volgende reël moet word. Dit is nie waar dat daar vir die groot meerderheid van sake in die werklikheid 'n heersende beskrywing bestaan nie. Die funksie van metafore kan nie tot die domein van die retoriek beperk word nie. Sonder metafore sal ook beskrywende taal baie armer wees of selfs so gebrekkig wees, dat dit onbruikbaar word.

Luther toon oortuigend aan dat taal nie volledig vanuit die perspektief van die tekenfunksie wat taal sou hê, beskryf kan word nie. Metaforiese taal kan beter vanuit die perspektief van die gelykenisfunksie van taal beskryf word. Dit beteken egter nie dat Luther se eie standpunt nie ook problematies is nie.

Heinrich Ott (1973:414-415) lig as eksistensiale teoloog die vernaamste leemte in Luther se metafoorteorie uit, wanneer hy aanvoer dat die substansie-denke van Luther nog in so ' $n$ mate vasgevang was in die ontologiese denke van die laat-Middeleeue, dat hy, ondanks sy insig in die probleme wat met die verstaan van die tradisionele metafoorteorie saamhang, self nie 'n bevredigende oplossing vir hierdie probleme kon gee nie. Luther het byvoorbeeld raakgesien dat dit by die instellingswoorde van die Nagmaal nie net om die brood as 'n blote teken van Jesus se teenwoordigheid gaan nie, maar wel daaroor dat Christus in der waarheid teenwoordig is. Dit beteken, volgens Ott, nou nie dat Christus op ' $n$ magiese wyse in die brood en wyn teenwoordig is, soos wat Luther beweer nie. Sy teenwoordigheid is nie substantief, ontologies van aard nie, maar persoonlik. Hy is nie as stof by die Nagmaal teenwoordig nie, maar as persoon. Die taal van die Bybel is nie die ontologiese taal van die laat-Middeleeue nie. Die vraag kan met goeie reg aan Ott gestel word of die personalistiese taal van sy weergawe van die eksistensiale teologie, wel met die taal van die Bybel korrespondeer. Watter sekerheid het hy dat sy interpretasie van die sake nou juis getrouer aan die saak van die Bybel is as dié van Luther? Al wat Ott met sy betoog aantoon, is dat sy eie inter- 
pretasie vandag meer aanvaarbaar is vir die eietydse mense as dié van Luther. Elke nuwe geslag gaan van sy eie verwysingsraamwerk uit en het daarom 'n behoefte dat geykte taal so vertaal word dat dit by die heersende verwysingsraamwerk inpas.

Toe die instellingswoorde van die Nagmaal in die Bybel opgeteken is, is die fondament reeds daarvoor gelê dat hierdie woorde so uitgelê sou moes word. Die metafore 'Dit is my liggaam' en 'Dit is my bloed' het inherent die krag gehad om 'n werkingsgeskiedenis tot gevolg te hê. Hierdie werkingsgeskiedenis is in die loop van die kerkgeskiedenis gerealiseer, maar dit het nog nie tot afsluiting gekom nie. Om vandag, na soveel wat gebeur het, na die betekenis van hierdie metafore te vra, beteken dat ons nie anders sal kan vra as om ook na die begripsgeskiedenis van die metafore te vra nie. Dit is 'n saak wat egter nie in die denke van Luther tereggekom het nie. Luther het wel die gelykeniskarakter van metafore ontgin, maar hy het nooit ' $n$ sensitiwiteit vir die meegaande begripsgeskiedenisse van metafore ontwikkel nie.

\section{KANT}

Uit die geskiedenis van die metafoorteorie is dit duidelik dat dit veral die denke van Aristoteles en Nietzsche was wat invloed op die proses van die teorieontwikkeling oor metafore uitgeoefen het. Die denke van Kant het egter ' $n$ bepaalde wending aan sake rondom die bestudering van metafore gegee wat nie misgekyk kan word nie. Dit is opvallend dat Kant nie in die eerste plek 'n metafoorteorie ontwerp het nie, maar dat hy by uitstek ' $n$ gebruiker van metafore was. Dat dit die geval is, is nie toevallig nie. Sonder dat Kant dit in soveel woorde uitspel, kan mens uit die karakter van sy filosofie agterkom dat hy die eerste filosoof was wat 'n sensitiwiteit daarvoor ontwikkel het dat metafore nie taalformules met vaste betekenisse is nie, maar dat dit 'n vorm van taal gebruik is wat oop is vir ontginning en gebruik kan word om sake in woorde vas te vat wat andersins baie moeilik onder woorde gebring kon word.

Wanneer ' $n$ mens wil probeer om die rol van metafore in die filosofie van Kant aan te dui, is dit dalk die beste strategie om dit aan die hand van 'n enkele voorbeeld te doen. 'n Voorbeeld wat die saak baie goed kan illustreer, is die metafoor oor die Kopernikaanse wending in die filosofie van Kant. Kant gebruik hierdie metafoor in die voorwoord van die tweede uitgawe van die Kritik der reinen Vernunft wat in 1787 verskyn het. Hanson (1959:274-281) praat van die hermeneutiese sleutelfunksie wat aan dié metafoor in baie van die prominentste interpretasies van Kant se Kritik der reinen Vernunft toegeken is, as 'n las wat dié interpretasies met hulle moet saam dra. Hierteenoor wil ek hier aantoon dat die metafoor wel betrekking het op en aanskoulik aangewend kan word ten opsigte van die sentrale sake waarin dit in sowel die voorwoord as die teks van die Kritik der reinen Vernunft gaan. 
Die feit dat Kant die metafoor eers ses jaar na die oorspronklike uitgawe van die Kritik der reinen Vernunft gebruik, dui daarop dat die metafoor sy oorsprong het in Kant se ervaring van die werkingsgeskiedenis van die teks in daardie eerste ses jaar na die verskyning van die werk. Hermann Cohen (1907:2) het die waarneming gemaak dat Kant by die gebruik van die metafoor, ook nie langer as die outeur van die werk aan die woord is nie, maar self as 'n leser van die werk skryf. Kant gebruik die metafoor as 'n retoriese middel om aan die ander lesers van die werk 'n sleutel tot die verstaan van die werk te bied. So hoop Kant om die werk wat nie van die begin af met ope arms ontvang is nie, by ' $n$ breër publiek aan te beveel. Die vraag ontstaan egter hoe hy hierdie metafoor vir dié doel gebruik?

In meer as een opsig is die metafoor van ' $n$ Kopernikaanse wending in die filosofie van Kant (en daarom in die filosofie as sodanig) 'n onwaarskynlike metafoor. Aan die einde van die agtiende eeu is dit nie meer moontlik om jou op ' $n$ outoriteit uit die verlede te beroep in ' $n$ poging om vertroue te skep nie, want vertroue kan alleen nog gewen word deur na 'n wetmatigheid van die geskiedenis te verwys (Blumenberg 1989a:692). Dit beteken dat die prototipiese figuur van Kopernikus nie meer 'n eksemplariese betekenis kan hê nie, omdat hy nie meer enige inhoudelike noodwendigheid kan verteenwoordig nie, maar nog net 'n moontlikheid kan aantoon (Blumenberg 1989a:692). Volgens Kant, kan ons verder redeneer, het Kopernikus nie die natuurwetenskaplike metode verander nie, maar net 'n nuwe model aangebied waarbinne wetenskap bedryf kan word. Dit beteken dat hy nie 'n werklike vernuwer van die wetenskap was nie (Blumenberg 1989a:697). Hierdie beskouing word bevestig deur die feit dat die naam van Kopernikus nie weer gebruik word in die res van die Kritik der reinen Vernunft om as analogie te dien nie. Die naam van Kopernikus word ook nêrens deur Kant in 'n kanonieke lys van name van persone wat 'n eksemplariese bydrae gelewer het tot die geskiedenis van die wetenskap, opgeneem nie. As die Kopernikaanse metafoor in die lig van hierdie argumente dan so onwaarskynlik is, waarom het Kant dit dan wel ingespan en wat wil hy presies daarmee sê?

Die Kopernikaanse wending in die metafisika kom ter sprake teen die agtergrond van twee revolusies wat in die geskiedenis van die wetenskap plaasgevind het. Die eerste was 'n revolusionêre insig van die Grieke op die gebied van die wiskunde. Hierdie insig, om 'n volgende Kantiaanse metafoor te gebruik, het 'n nuwe lig vir die mens laat opgaan. Die nuwe insig van hierdie vroeë denkers was dat die mens se kennis nie vooruitgegaan het vanweë dit wat hy in 'n gelyksydige driehoek waargeneem het nie, maar vanweë dít wat hy a priori, deur die gebruik van begrippe self, in die konstruksie ingelê het. Die volgende revolusionêre wetenskaplike wending het op die gebied van die natuurwetenskappe gekom en het weer vir die navorsers van die natuur 'n nuwe lig 
laat opgaan. Hierdie mense het begryp dat die rede net dit insien wat deur die rede self deur middel van sy eie ontwerpe na vore gebring is. Die rede werk deur sekere beginsels waardeur hy oordeel en hierdeur word die natuur gedwing om op die vrae van die rede te antwoord. Hierdie insigte het Kant op die spoor geplaas om ook 'n revolusionêre insig met betrekking tot die metafisika aan te kondig, naamlik dat mens vroeër aangeneem het dat al ons kennis op die objekte van ondersoek gerig was. Hierdie beskouing het egter tot niks gelei nie, daarom vra Kant homself die vraag af of dit dalk nie die taak van die metafisika is om aan te dui dat sake eerder in 'n omgekeerde verhouding tot mekaar staan nie, naamlik dat die objekte van ondersoek hulle na ons kennis rig, en dat daar deur hierdie proses vooruitgang op die gebied van die kennis kom. Sou hierdie gebeure op die gebied van die metafisika as die Kopernikaanse daad van Kant beskryf word, is dit moeilik om in te sien waarom die daad nou juis as Kopernikaans getipeer moet word. Daarom is dit ook nodig om die wyer konteks van die Kantiaanse vraagstelling onder oë te neem.

Kant neem ook twee ander wendings in die naturwetenskap van sy eie tyd ter harte, naamlik die eksperimentele metode en die metafoor van die regterlike rol van die rede in die kenproses. Die mens moet wanneer hy wetenskap wil bedryf, 'n hipotese opstel wat hy dan later deur middel van eksperimente in die natuur deur die natuurlike verskynsels laat bevestig of verkeerd laat bewys. In hierdie proses speel die rede die rol van 'n regter: Die regter vra aan sekere getuies vrae waarop hulle moet antwoord; die natuur moet antwoorde gee op die vrae van die rede. Dit is in hierdie verband dat Kopernikus ' $n$ besliste rol gespeel het. Hy het 'n hipotese opgestel wat eers later deur die fisika van Newton bevestig is, en so het hy die aandag op die rol van die hipotese en die eksperimentele metode gevestig. Kopernikus het homself die vraag afgevra of dit nie beter (naamlik eenvoudiger) sal wees om teenoor die tradisionele opvatting, naamlik dat die sterrehemel om die toeskouer wentel, te aanvaar dat die toeskouer om die sterrehemel wentel nie.

Die geregshofmetafoor het 'n hele nuwe perspektief vir Kant oopgemaak, om sowel die stand van die filosofie in sy eie tyd as die verhouding tussen die teoretiese rede en die praktiese rede te beskryf.

Die rede staan nie bo die geskiedenis nie, maar word deur die geskiedenis bepaal. Kant kritiseer in sy wetenskapskritiek sowel die denke van die dogmatiese as die rasionalistiese filosowe. Wat hy egter nie doen nie, is om homself met hierdie kritiek bo die geskiedenis te probeer plaas nie. Die metafisika is niks meer as 'n Herumtappen en beslis nie ' $n$ wetenskap nie. Dit wil egter nie sê dat dit nie 'n noodwendige voorwaarde was vir die ontstaan van die kenkritiek van Kant nie. Uit die geskiedenis leer Kant dat die metafisika vals is. Uit sy ervaring met die metafisika besef hy dat 'n 
radikale kenkritiek onontbeerlik is. Uit die valse metafisika van die verlede ontstaan 'n radikale kenkritiek en so ook 'n wetenskaplike filosofie. Wat egter hier van belang is, is dat Kant hierdie gebeure met die gebruik van die Kopernikaanse metafoor beskryf het.

Kant was die eerste filosoof om die rasionalistiese wetenskapsideale van die Verligting te kritiseer. Hy beperk die teoretiese rede wat met die wiskundige paradigma werk, tot die domein van die ervaring en skep so ruimte vir 'n praktiese filosofie in eie reg. Kant se eie filosofie moet as 'n praktiese filosofie wat op die bemiddeling van vryheid uit is, verstaan word. Vir Kant gaan dit daaroor om die teenspraakvrye bestaan van sowel vryheid as natuurlike determinisme te verduidelik (Kaulbach 1969:113). Hier is die Kopernikaanse metafoor weer van belang. Die vergelyking van Kopernikus en Newton word eksemplaries gebruik om die verhouding van die teorie van die praktiese rede tot die teoretiese rede as analoog met die verhouding tussen hipotese en eksperiment te beskryf.

Die grondreel wat Kant vir die praktiese filosofie opgestel het, is dat die geldigheid van norme deur die vorm van redelike algemeenheid bepaal word. Hy kon hierdie grondreël opstel omdat hy ook 'n radikale kenniskritiek deurgevoer het. Kant gaan nie meer, soos sy voorgangers, op 'n onkritiese wyse van die standpunt uit dat die teoretiese en die praktiese gebruik van die rede identies is en van die wiskundige paradigma moet uitgaan om as redelik te geld nie. Die praktiese rede funksioneer onafhanklik van die teoretiese rede, en die morele wette kan alleen redelik wees wanneer dit bewys kan word dat plig voor alle ervaring in die wil van die mens gesetel is. Op hierdie wyse stel Kant 'n nuwe paradigma op, naamlik die paradigma van die subjekgesentreerde rede. Die praktiese filosofie sou in die toekoms deur hierdie paradigma bepaal word.

Dit is veral Russell (kyk Blumenberg 1989a:709) wat op hierdie standpunt kritiek gelewer het. Hy is van mening dat die Kopernikaanse metafoor misplaas is binne die konteks waarin Kant dit gebruik, en hy stel voor dat Kant eerder van 'n Ptolemaïese kontrarevolusie moes gepraat het. Die rede vir hierdie kritiek lê daarin dat Russell van mening is dat Kopernikus daarin geslaag het om die mens uit die middelpunt van die kenproses te skuif, maar dat Kant die mens deur sy praktiese filosofie weer in hierdie ereplek teruggeplaas het. Dit is duidelik dat Russell nie die volle impak van Kant se kenkritiek (en daarom ook nie sy metaforiek) begryp het nie. Vir Kant gaan dit daaroor dat die kennis van die natuur nooit die gevolg kan hê dat die mens bereid sal wees om grense aan sy rede te stel nie. Dat die mens grense vasstel waarbinne hy met sy redelikheid kan beweeg, is alleen die resultaat van 'n radikale kenniskritiek. Dit is juis hier waar die tertium comparationis van die Kopernikaanse metafoor gesoek moet 
word. Dit was die prestasie van die kritiek van die suiwer teoretiese rede dat die praktiese rede moontlik gemaak is, deurdat die teoretiese rede terugwerkend deur die selfindentifikasie van die praktiese rede bevestig kon word. Dieselfde geld vir Kopernikus se bydrae tot die wetenskap. Alle resultate van die wetenskap wat ná Kopernikus bereik is, sou dalk onontdek gebly het as Kopernikus dit nie gewaag het om op 'n weerbarstige wyse die beweging van die hemelruim nie in die planete te soek nie, maar in die toeskouer van die hemelruim.

Kant het met sy filosofie die oorgang van die teoretiese na die praktiese rede oor dink. Hy beperk die domein van die teoretiese rede, omdat hy van oortuiging is dat die teoretiese rede onmagtig is op enige gebied wat nie deur die mens se ervaring gedek kan word nie. Die teoretiese rede het daarom ook op die gebied van die moraliteit nie enige mag nie. Met hierdie insig in gedagte wil Kant nie aan die teoretiese rede enige morele of politieke reddingskrag toeskryf nie. Deur sy verdere redenasie dat die praktiese rede wel kan bewys dat plig voor alle ervaring in die wil van die mens gesetel is, ontwerp Kant nie alleen die nuwe paradigma van die subjekgesentreerde rede nie, maar ontwerp hy ook sy leer oor die 'ryk van die doeleindes'. Hierdie leer handel daaroor dat die mens moet lewe asof hy in 'n staatkundige werklikheid lewe waarin mense as menslike mense kan lewe. Die woordjie 'asof' dui daarop dat die ryk van die doeleindes nie 'n realiteit is nie en dit ook nooit sal kan word nie. Net soos die teoretiese rede, is die praktiese rede ook 'n vorm van redelikheid sonder enige mag. Kant, ontnugter deur die onmag van die teoretiese rede en op soek na 'n ander vorm van redelikheid wat die mens kan inspan om homself te red, ontdek dat die praktiese rede ook onmagtig is wanneer die mens se redding ter sprake kom. Die besef dat die praktiese rede onmagtig is, dwing Kant om aan sy filosofie 'n estetiese wending te gee in ' $n$ poging om die moderne mens nie algeheel uit te lewer aan die noodwendigheid van die natuur in die lig van die swak magsprestasie van die rede nie. Die goeie syn wat nie gerealiseer kan word nie, kan egter wel gesimboliseer word. Die estetiese rede besit mag, maar die mag wat dit besit, is nie 'n mag wat iets kan verwerklik nie; dit is net 'n mag wat iets kan simboliseer (Kant 1983c:461). Die skone is die simbool van die sedelik goeie (Kant 1983c:461). Die moontlikheid dat die goeie gesimboliseer kan word, het die mens bevry van die selfopgelegte dwang om homself te emansipeer deur die gebruik van die rede, sonder om die gevolg te hê dat die mens weer aan die determinisme van die natuur verslaaf word.

Kant het met die estetiese wending wat hy aan sy eie filosofie gegee het, nie in die duisternis ingespring in 'n poging om van die gebruik van die rede te probeer wegkom nie. Hy het net die rol beperk wat die rede in die emansipasie van die mens speel. Die rede kan nie gebruik word om die mens te emansipeer nie, maar wel om teen enige vorm van verslawing of onderdrukking te veg en so die hoop vir 'n mensliker toekoms lewendig te hou. 
Kant se beskrywing van 'n kunswerk as die daarstelling van "n estetiese idee is ook hier van belang. Kant het nie met die kunsteorie wat hy in sy Kritik der Urteilskraft ontwikkel het, daarin geslaag om bevredigend te kon aantoon hoe mooi kunswerke tot stand kom nie. Dit beteken egter nie dat hy nie kon aandui wat kunswerke vir die mens beteken en wat die sin daarvan is nie (Kulenkampff 1979:68). Die kunswerk as 'n estetiese idee is, volgens Kant, iets wat die mens baie dinge laat sien, hoor, ontdek en verstaan. ' $n$ Kunswerk as 'n estetiese idee, is 'n veelduidig betekenisvolle skepping (Kulenkampff 1979:69). Dit is die dinge wat mooi is, wat die mens (met sy teoretiese en sedelike insig) daarvan kan oortuig dat hy deel van een wêreld is (Kulenkampff 1979:72). Die kunswerk as 'n estetiese idee oortuig die mens daarvan dat die wêreld een is, maar dan egter op so 'n wyse dat dit 'n groot verskeidenheid aanbied om te sien, hoor en te ken. Hierdie standpunt van Kant laat hom die ervaring van dit wat mooi is, verstaan as 'n samespel van die verbeeldingskrag en die verstand en nie as iets wat deur die gebruik van begrippe beskryf kan word nie. Wellmer (1985:36-37) is van mening dat die kunservaring, soos wat dit deur Kant beskryf is, op die moontlike herstel van die verband tussen kuns en leefpraksis dui, want die omslag van die estetiese ervaring in simboliese of kommunikatiewe handeling dui daarop dat daar tog wel 'n verband tussen kuns en leefpraksis bestaan. Wellmer is verder van mening dat hierdie stand van sake daarop dui dat waarheid nie op 'n 'onmetaforiese' wyse uit die kuns afgelees kan word nie. Om te probeer aandui wat Wellmer met die uitdrukking 'onmetafories' bedoel, kan daar na sy volgende uitspraak verwys word om die saak te verduidelik:

\begin{abstract}
Die Kunstwahrheit erschien dabei als ein Interferenzphänomen der verschiedenen Dimensionen des alltäglichen Wahrheitsbegriffs. Dieser freilich ist mit einer utopischen Perspektive verknüpft: der einer gewaltlosen Kommunikation .... Gewaltlose Kommunikation aber bedeutet nicht die Aufhebung der Kunst; das Kunstschöne steht nicht für das Ganze der Vernunft, vielmehr bedarf die Vernunft der Kunst zu ihrer Erhellung: ohne ästhetische Erfahrung und ihre subversiven Potentiale müssten unsere moralischen Diskurse blind und unsere Interpretationen der Welt leer werden.
\end{abstract}

(Wellmer 1985:43)

Kant het met sy filosofie nie die populêr geykte siening van metafore, wat vroeër beskryf is, teoreties probeer weerlê nie. Hy het egter aangetoon dat metafore nie alleen 'n beperkte retoriese funksie het nie, maar dat die gebruik van 'n metafoor wenslik of selfs onontbeerlik kan wees om insig in 'n sekere saak te kry, of om die proses van 
kennisverwerwing te laat voortgaan. Die wetenskapsgeskiedenis self vertoon by geleentheid selfs 'n besliste metaforiese karakter, omdat sekere wetenskaplike ontwikkelings nie anders as in terme van metafore beskryf kan word nie. Die metafoor - as 'n uitdrukkingsvorm van die estetiese rede - red die mens ook van sy selfopgelegte emansipasiedwang, omdat hy 'n metafoor kan inspan om die goeie syn te simboliseer en so $\sin$ aan sy eie lewe toe te voeg. Hierdie feit laat die vraag ontstaan of die taal self nie ook 'n metaforiese karakter kan aanneem nie, met die gevolg dat die onderskeidings tussen werklike en vreemde name, definisiegerigte en retoriese taal gebruik en uitsprake en aanspreke baie kunsmatig voorkom.

Met Kant se filosofie het die historiese bewussyn duidelik 'n stewige staanplek in die filosofie verower. By Luther is nog net 'n sluimerende historiese bewustheid te bespeur, met die gevolg dat hy nog nie daarin kon slaag om 'n sensitiwiteit vir die moontlikheid van begripsgeskiedenisse van metafore te openbaar nie. Na Kant se metaforiese beredenering rondom die ontwikkeling van die wetenskapsgeskiedenis, is ' $\mathrm{n}$ metaforologie nouliks anders as die ontwikkeling van begripsgeskiedenisse moontlik. Nog meer, dit word ' $n$ vraag of mens nie beter insig in die betekenis van metafore kan kry nie met ' $n$ metaforologie wat as 'n begripsgeskiedenis bedryf word, eerder as deur 'n teorie van metafore. Hierdie moontlikheid word deur Nietzsche in die visier gebring.

\section{NIETZSCHE}

In sy filosofie polemiseer Nietzsche teen 'n begrip van waarheid wat daarvan uitgaan dat ' $n$ woord as 'n teken ooreenstem met 'n sekere saak, want dit is moontlik dat sake met woorde kan korrespondeer wat as begrippe bekend staan, omdat 'n absolute betekenis daaraan toegeken word. Hierteenoor stel Nietzsche dat elke woord se ontstaan op 'n eenmalige en individuele gebeurtenis teruggaan, maar dat die woord dan ook later op tallose gevalle toegepas word wat in 'n mindere of meerdere mate ooreenstem met die oorspronklike gebruik van die woord, maar nooit volkome gelyk daaraan is nie (Nietzsche 1968:101). Op hierdie wyse, meen hy, word 'n woord 'n begrip. Elke begrip ontstaan deur die gelykstelling van ongelykes (Nietzsche 1968:101). Dit wat ongelyk is, word weggelaat en so word 'n gelykheid gekonstrueer wat in werklikheid nie bestaan nie. Nietzsche vra byvoorbeeld wat eerlikheid is. Dit is volgens hom 'n hele aantal individuele handelinge wat gelyk gemaak is deurdat die ongelykes van die handelinge weggelaat is, sodat ons 'n qualitas occulta met die naam 'eerlikheid' formuleer. Nietzsche meen dat dit uit hierdie verloop van sake duidelik is dat die waarheid niks anders as ' $n$ illusie is nie. Waarhede is illusies, omdat dit enersyds metafore is waarvan mens die metaforiese karakter vergeet het en andersyds afgestomp en kragteloos geword het (Nietzsche 1968:102). 
Die verharding en verstarring van 'n metafoor waarborg nie die noodwendigheid of die legitimiteit van die metafoor nie. $\mathrm{Al}$ wat daardeur gewaarborg word, is 'n rus en sekerheid wat daarop berus dat die mens homself as subjek, en dan as kunstig skeppende subjek wat die begrip gebou het, vergeet. So sluit die selfbewuste mens hom van die werklikheid af (Nietzsche 1968:105). Die mens verloën deur die tradisionele waarheidsopvatting (veritas est adaequatio rei et intellectus) sowel die antropomorfiese aard van taal as homself as die skeppende subjek van taal. In der waarheid dwing die mens homself daartoe om volgens vaste konvensies te lieg en dan te vergeet dat hy dit gedoen het. Hy lieg onbewus, as gevolg van 'n eeue-oue gewoonte en kom deur hierdie onbewustheid en vergetelheid tot 'n gevoel van waarheid (Nietzsche 1968:103).

Nietzsche neem sy vertrekpunt in die beskrywing van mense se omgang met metafore, en deur metafore met mekaar en die wêreld in die antropologie. Die mens is nie soos diere biologies gespesialiseerd om in ' $n$ bestaansvyandige wêreld te kan oorleef nie. Die mens probeer egter om sy biologiese agterstand uit te wis deur 'n net van simboliese vorms oor die natuur te werp, om sodoende die dreigende wêreld onder sy kontrole te bring. Nietzsche (1968:105) noem die krag om deur die gebruik van simboliese vorms sin te ontsluit, "n drif tot die ontwerp van metafore'. Die fiktiewe wêreld van simbole word in diens van die bevrediging van elementêre behoeftes aangewend. Die mens beskerm homself van die wêreld deur 'n selfgemaakte kleed van metafore om hom te vou.

Soos reeds gesê is, sien Nietzsche ook 'n gevaar in die gebruik van metafore raak. Wanneer metafore tot konvensies verstar, begin die mens om in ' $n$ fantasiewêreld te leef. Metafore kry dan die skyn van waarheid (Nietzsche 1968:103). Die mens kan alleen uit hierdie droomwêreld bevry word wanneer hy begin om deur die gebruik van abstrakte begrippe ' $n$ intersubjektiewe wêreld te begrond. Die ontwerp van sulke begrippe is egter ' $n$ ingeboude kwaliteit van alle taal. In die grammatika van die taal is reëls ingebou waarvolgens metaforiese inhoude kategoriaal georden kan word. Elke kunstige ontwerp van metafore veronderstel reeds vorms van taalgebruik wat vooraf vasgelê is (Nietzsche 1968:108).

Nietzsche is van mening dat die inhoud van metafore nie so belangrik is as die funksiewaarde van die vorm nie. Wanneer 'n metafoor ingespan word om 'n menslike behoefte te bevredig, is dit nie belangrik met watter middele die metafoor die doel bereik waarvoor dit ingespan word nie. Dit is belangrik dat dit wel die doel bereik waarvoor dit gebruik word. In hierdie opsig is ' $n$ metafoor 'n magsinstrument wat in diens van die wil tot mag staan.

Watter rol speel die wetenskaplike bestudering van metafore dan? Die wetenskap het die funksie om die kategorieë wat in taal ingebou is, só te ontvou en te objektiveer dat dit geanaliseer kan word met die oog op tegniese aanwending. In die lig van hierdie beskouing reken Nietzsche dat dit die taak van 'n teorie van wetenskaplike kennis is 
om Kant se transendentale bewussynskritiek op die vlak van die taallogika, te herhaal. Dit beteken dat die teoretikus sal probeer om die kategorieë vir die ordening van metaforiese inhoude, transendentaal uit die taal af te lei. Vanuit hierdie perspektief kan Nietzsche (1968:173) dan ook krities met die filosofie van Kant omgaan.

Kant het die rede se vooroordele sintetiese oordele a priori genoem. Die rede se vooroordele is in die struktuur van taal gewortel en die identiteit van die taalvaardige subjek waaruit Kant die eenheid van die transendentale bewussyn in sy geheel - dit is die wêreldkonstituerende $\mathrm{Ek}$ - afgelei het, is ook 'n linguistiese funksie van taal. Dit beteken dat die kategorieë nie meer in die Kantiaanse sin van die woord transendentaal kan wees nie, maar nog net as ervaringsgegewenes wat histories dialekties akkumuleer en verskuif. Die gevolg van hierdie insig van Nietzsche is dat hy die vraag 'hoe is sintetiese oordele a priori moontlik?', met die vraag vervang 'waarom is dit nodig om aan sulke oordele te glo?'. Sintetiese oordele wat a priori gemaak word, is nie meer in die sin transendentaal dat dit noodwendige geldigheid besit nie, maar nog slegs in die sin dat dit noodwendige voorwaardes vir enige taalmatige interpretasies van die werklikheid is. Volgens Nietzsche kan dit nie meer daarom gaan dat sekere uitsprake waar is nie, maar nog net daarom dat die vraag beantwoord moet word waarom cit nodig is om sekere uitsprake as waar te veronderstel.

Nietzsche se antwoord op die vraag waarom dit nodig is om sekere uitsprake as waar te veronderstel, is kort: ons het niks wat ons nie nodig het nie en ons het niks op 'n bepaalde manier, as ons dit nie op daardie bepaalde manier nodig het nie, maar dit op 'n ander manier kon gehad het (Nietzsche 1968:178). Ons gebruik metafore op die manier waarop ons dit wel gebruik, omdat ons dit nodig vind om dit te doen. Sonder metafore kan ons nie in hierdie vyandige wêreld oorleef nie. Dit beteken egter nie dat metafore ons tot hulp kan wees om die waarheid te ontsluit nie.

Nietzsche voer die waarheid na metaforiese gebeure terug, omdat hy van mening is dat daar tussen twee absoluut verskillende sfere, byvoorbeeld subjek en objek, geen kousaliteit of korresponderende korrektheid kan bestaan nie, maar hoogstens 'n estetiese verhouding waarin een saak nabootsend in die gans vreemde taal van die ander saak vertaal kan word (Nietzsche 1968:106). Wie, vra Nietzsche, sal dit ontken dat taal in die harde wêreld van die dinge 'n algeheel vreemde saak is? Die oorgang van syn na taal kan nie anders as metafories van aard wees nie. Dit beteken dat die waarheid net ' $n$ ander naam is vir ' $n$ absolute metafoor (of ' $n$ metafoor waarby die oorgang van syn na taal in vergetelheid geraak het). 


\section{SLOT}

Jüngel (1980:142) wys aan die hand van Nietzsche daarop dat daar tussen drie sake onderskei moet word:

* taal word deurgaans daardeur bepaal dat die formulering van enige waarheid in der waarheid die 'vertaling' of omskakeling van die syn in taal is, met die gevolg dat waarheid altyd as $\mu \varepsilon \tau \alpha \phi o \rho \alpha$ getipeer kan word;

* taal het deurgaans 'n metaforiese struktuur wat veral in sekere metafore en gelykenisse besonder aanskoulik aan die lig kom en as die verwisseling van mens en wêreld die sprekende kern van taal uitmaak;

* daar is bepaalde metafore wat in die taal gebruik word en as herinnering daartoe dien dat sowel taal as waarheid 'n metaforiese struktuur vertoon.

Jüngel kom egter aan die hand van die bogenoemde redenasie tot ' $n$ ander waardering van die funksie van metafore met betrekking tot die waarheidsvraag as Nietzsche self. Hy meen metafore is op so ' $n$ wyse die beweging van die syn in die taal, dat hierdie beweging in die taal voortgesit word en só die taal sowel as die synsbetrokkenheid van die mens verruim. Metafore laat ' $n$ mens aan die waarheid deelneem deurdat dit die werklike sy werklikheid laat oorstyg sonder om iets vals daaroor uit te spreek (Jüngel 1980:143). Wanneer die werklike sy werklikheid deur middel van metaforiese taal oorstyg, word die werklikheid self gespesifiseer en op 'n bepaalde fokuspunt gerig. 'n Metafoor sê ongetwyfeld meer as wat in die werklikheid opgesluit is, maar bly terselfdertyd aan die waarheid getrou. Metaforiese skyn bedrieg nie. Dit ontgin egter net die aansprekende karakter van taal wat vir die mens dit moontlik maak om homself en die wêreld te ontdek (Jüngel 1980:143). Anders as die tradisionele opvatting kan Jüngel daarom sê dat daar nie 'n eenrigtingpad van mite na logos loop nie, maar dat daar 'n wisselwerkende dialektiek bestaan tussen mite en logos, simbool en begrip, metafoor en werklike naam, aanspreke en uitsprake. Narratiewe en argumentatiewe taal hoef mekaar nie te weerspreek nie. Dit kom daarop neer om die veelkantige aard van taal raak te sien en gevolglik taal reg te gebruik. Uit ervaring weet ons dat 'n geslaagde metafoor homself nie hoef te bewys nie (Jüngel 1980:144).

Aan die hand van Aristoteles en Luther se denke is aangetoon dat sowel waarheid as wetenskap nie net deur middel van uitsprake of argumentatiewe taal verwoord word nie, maar ook deur middel van aanspreke en narratiewe taal. Die waarheid moet nie 
net ontdek word nie, maar ook gepropageer word. Die geskiedenis van die wetenskaplike ontwikkeling kan nie anders vertel word as deur 'n narratief nie. Aan die hand van Kant se denke is dit aangetoon dat die ontdekkingskonteks en die propageringskonteks nie so verskillend is as wat mens mag aanvaar nie en dat hierdie twee kontekste soms ineenvloei en mekaar wedersyds bepaal. Met Nietzsche se denke het die ontwikkeling wat hier beskryf is, tot 'n hoogtepunt ontwikkel. Na Nietzsche is dit nie meer moontlik om wetenskaplik-argumentatiewe taal vir die verwoording van die waarheid te reserveer nie. Die waarheid het ook 'n metaforiese kant. 'n Eietydse metaforologie sal hierdie waarneming deeglik moet verreken om geloofwaardig te kan wees.

Die redekritiese tradisie wat hier aan die orde gestel is, die narratologiese aard daarvan en die wyse waarop dit metafore in wetenskapsteoretiese narratiewe inspan, het die vraag laat ontstaan of ' $n$ teorie die beste middel is om ' $n$ narratologiese aangeleentheid, soos die gebruik van metafore, mee te ondersoek. Sal 'n narratologiese metaforologie, met ander woorde 'n nadenke oor metafore in die vorm van begripshistoriese narratiewe, nie beter vir dié doel aangewend kan word nie? Die waarnemings wat hier gemaak is, dui daarop dat 'n eietydse kritiek van die rede onontbeerlik is vir die beskrywing van ' $n$ eietydse konteks waarbinne die nadenke oor metafore plaasvind.

\section{Literatuurverwysings}

Aristoteles 1936. De caelo. Edited by Allen D J. Oxford: University Press. 1949. Categoriae et liber de interpretatione. Edited by Minio-Paluello L. Oxford: University Press.

1959. Ars rhetorica. Edited by Ross W D. Oxford: University Press. 1965. De arte poetica liber. Edited by Kassel R. Oxford: University Press.

Blumenberg, H 1989a. Die Genesis der kopernikanischen Welt. 2 Aufl. Frankfurt am Main: Suhrkamp.

Habermas, J 1983. Moralbewußtsein und kommunikatives Handeln. Frankfurt am Main: Suhrkamp.

Hanson, N R 1959. Copernicus' role in Kant's Revolution. Journal of the History of Ideas 20, 274-281.

Jüngel, E 1980. Entsprechungen: Gott-Wahtheit-Mensch, in Theologische Erörtungen.

München: Kaiser.

Kant, I 1976. Kritik der reinen Vernunft. Hamburg: Felix Meiner.

1983. Über das Misslingen aller philosophischen Versuche in der Theodizee,

in Werke. Darmstadt: Wissenschaftliche Buchgesellschaft. 
Kant, I 1983a. Grundlegung zur Metaphysik der Sitten, in Werke. Darmstadt: Wissenschaftliche Buchgesellschaft.

1983b. Kritik der praktischen Vernunft, in Werke. Darmstät: Wissenshaftliche Buchgesellschaft.

- 1983c. Kritik der Urteilskraft, in Werke. Darmstadt: Wissenschaftliche Buchgesellschaft.

Kaulbach, F 1969. Immanuel Kant. Berlin: De Gruyter.

1973. Die Copernicanische Denkfigur bei Kant. (Kant-Studien 64.)

Kulenkampff, J 1979. Über Kants bestimmung des Gehalts der Kunst. Zeitschrift für philosophische Forschung 33/1, 62- 74.

Luther, M 1883-. Kritische Gesamtausgabe. Weimar. (WeimaranalWA.)

Nietzsche, F 1968. Erkenntnistheoretische Schriften. Frankfurt am Main: Suhrkamp.

Ott, H 1973. Die Antwort des Glaubens. Berlin: Kreuz Verlag.

Ricoeur, P 1981. Hermeneutics \& the human sciences. Cambridge: Cambridge University Press.

Wellmer, A 1985. Zur Dialektik von Moderne und Postmoderne: Vernunftkritik nach Adorno. Frankfurt am Main: Suhrkamp. 